\title{
Variations in Middle English local surnames
}

\author{
Md Abu Shahid Abdullah
}

\section{DOI: 10.18355/XL.2017.10.04.17}

\begin{abstract}
Although there are many local surnames in Middle English that originate from places still on map and can easily be identified, many of the surnames indicate nothing more than the place of origin. The article will focus on the factors behind the distortion and variation of Middle English ${ }^{1}$ local surnames, and surmises that they vary from place to place because of the way they are spelt, because of the phonetic change and, most importantly, because of the dialectal variation. Variations in local surnames also take place because of the distance a name travels from its origin, of addition of different suffixes, and of different peculiarities. Focusing on four Middle English local surnames with their variants, the article will talk about the etymology of the names, their variations, and the reasons behind their variations. In the case of Oakes, Noakes, and Roake, variations arise from grammatical misinterpretations or the knowledge of the function of prepositional elements. Initial $F$ - in the South was pronounced $V$ which we find in Venn and Fenn. Aston and Easton have the same etymology but they differ from each other on regional and phonological perspectives. Last but not least, Staniforth is a variant of Stanford where the variation arises because of the dialectal variations of suffix -ford and -forth.
\end{abstract}

Key Words: surnames, suffix, distortion, variation

\section{Introduction}

A local surname is a convenient term for all surnames derived from a particular locality or place, but these are of more than one type. There are many local surnames which derive from places still on the map and are easily recognisable but many of the surnames show or indicate nothing more than the place of origin. Besides the huge number of names derived from estates, towns and villages, there are many names from landscape features, such as Hill, Wood, and Field or from specific buildings or parts of buildings. The original words of many of the surnames are quite obsolete or they survive only in local dialect. Local surnames are one of the four types of surnames. They refer to place of origin and ownerships of lands. There are lots of variations in surnames and these variations take place because of different factors.

In my paper, I will talk about the distortion and variation of ME local surnames due to different reasons - the distance they travel from their birth-place, imitative tendency, and interesting and confusing endings - and shed light on different cases of suffix change. I will focus on four ME local surnames with their variants such as Aston and Easton; Oakes, Noakes, and Roake; Stanford and Staniforth; and Venn and Fenn. I will talk about the etymology of these names, their variations, and reasons behind their variations. Last but not least, I will show the distribution of the names in different counties in the UK based on the data from 1881, 1911, and $2004^{2}$.

\footnotetext{
${ }^{1} \mathrm{ME}$ will be used as the abbreviation of Middle English throughout the article.

${ }^{2} 1881$ census data are taken from the website www.forebears.co.uk. 1911 census data are taken from www.uk1911census.com which fails to provide data for Aston and Easton in some counties. All the data of 2004 are taken from the book An Atlas of English Surnames where no information regarding the discussed names is found in some counties like Middlesex, Sussex,

XLinguae, Volume 10, Issue 4, October 2017, ISSN 1337-8384, eISSN 2453-711X
} 


\section{Surnames: Origin, Types, Structure, and Variation}

"In Old English times people usually had only one name, the Christian name but at the end of the Old English period, the need of a second name was felt and by-names were used to differentiate between people with same personal name" (Fransson,1935: 20). Surnames came in vogue in the late $11^{\text {th }}$ century partly as a result of social changes following the Norman Conquest in 1066; in the $13^{\text {th }}$ century, one could rarely find a person mentioned only by his Christian name. They were passed on from one generation to the next and were markers of relationships rather than descriptions of individuals. After the Norman Conquest, Old English ${ }^{3}$ Christian names were totally changed and the Christian names of the Normans started to be used commonly although these names were limited. There were people with same Christian names in the same village and it was necessary to distinguish them by adding an extra name; later, other persons were also given a second name. When the Normans came to England, they brought second names with them and these names were added to those that already existed. Unlike Christian names, surnames could be changed. Before surnames became fixed as hereditary family names, a person could have two or more surnames at the same time and he could use different names in different times. Apart from some exceptions, surnames were considered as real names and used frequently for the sake of clarity (Fransson, 1935: 22-23).

ME surnames were divided into four classes: all surnames would fall into one or other of the four classes.

Local Surnames: This was by far the largest group of surnames held by landowning families, and referred to place of origin or to ownership of land. This is of two types:

$>\quad$ Locative Surnames: They derived from place-names or residence from where the person had come. For example, Tom de Appelby (Fransson, 1935: 26)

$>\quad$ Topographical Surnames: They were formed from topographical elements, and preceded by ate, de la, uppe, binethe. They denoted the residence of a person: Agnes ate More etc.

Surnames of Relationships or Familial Surnames: These names denoted a person's relationship and commonly contained the father's and rarely the mother's Christian name, and even his or her surname. Those from a father's name are known as 'patronymics' and those from a mother's name as 'matronymics'.

Surnames of Occupation or Office: The surnames of occupation were the most interesting names and could be divided into three possible groups. The first group contained dignitaries and officers, e.g. mayor, judge, sheriff, etc. The second group comprised occupations which belong to the country, such as agricultural and farming occupations, pastoral occupations and forestall occupations. The third and last group consisted of those who produced and sold different products.

Characteristic Surnames or Nicknames: These names were not taken by the bearer but were given to or imposed on them by other people; they even became hereditary. "Nicknames can be originated from different sources and are of different types, for example, physical and external peculiarities, mental and moral characteristics, from animals, fishes and birds, from oaths and phrase-names, and names of indecent and obscene association" (Reaney, 1978: 232).

Worcester and Yorkshire (East, North and West Riding). Mapping is done by using Google

Fusion Tables (www.tables.googlelabs.com)

${ }^{3} \mathrm{OE}$ will be used as the abbreviation of Old English throughout the article. 
It should be mentioned that there is considerable overlapping within these groups. Local surnames may be occupational Surnames of office such as Abbot, Bishop and King are often nicknames whilst the last two may also be patronymics (Reaney, 1978: 20). "The use of surnames gradually spread down the social scale, with occupational surnames associated particularly with skilled craftsmen, and characteristic surnames with the lower classes" (Hough, 2012: 219). One chart concerning the variations and distributions of local surnames is provided bellow:

\begin{tabular}{|c|c|c|c|c|c|c|}
\hline Place & Date & $\begin{array}{c}\text { Total No. } \\
\text { of } \\
\text { Persons }\end{array}$ & $\begin{array}{c}\text { Local } \\
\%\end{array}$ & $\begin{array}{c}\text { Relationship } \\
\%\end{array}$ & $\begin{array}{c}\text { Occupational } \\
\%\end{array}$ & $\begin{array}{c}\text { Nicknames } \\
\%\end{array}$ \\
\hline Winchester $^{4}$ & $\begin{array}{l}1066 \\
1115 \\
1148\end{array}$ & $\begin{array}{l}243 \\
274 \\
855\end{array}$ & $\begin{array}{c}8 \\
13 \\
13\end{array}$ & $\begin{array}{l}9 \\
6 \\
2\end{array}$ & $\begin{array}{l}13 \\
21 \\
26\end{array}$ & $\begin{array}{c}13 \\
9 \\
10\end{array}$ \\
\hline Kings Lynn ${ }^{5}$ & 1166 & 186 & 14 & 6 & 14 & 16 \\
\hline Newark $^{6}$ & $\begin{array}{c}\mathrm{C} \\
1175 \\
1225- \\
31\end{array}$ & $\begin{array}{l}365 \\
299\end{array}$ & $\begin{array}{c}7 \\
29\end{array}$ & $\begin{array}{l}5 \\
7\end{array}$ & $\begin{array}{c}23 \\
8\end{array}$ & $\begin{array}{l}9 \\
6\end{array}$ \\
\hline Shrewsbury $^{7}$ & $\begin{array}{c}1209- \\
19 \\
1384- \\
1415 \\
1450- \\
1459\end{array}$ & $\begin{array}{l}982 \\
511 \\
268\end{array}$ & $\begin{array}{c}8 \\
36 \\
37\end{array}$ & $\begin{array}{c}4 \\
7 \\
16\end{array}$ & $\begin{array}{l}18 \\
11 \\
12\end{array}$ & $\begin{array}{c}7 \\
9 \\
12\end{array}$ \\
\hline London $^{8}$ & $\begin{array}{l}1292 \\
1319 \\
1332\end{array}$ & $\begin{array}{c}805 \\
1860 \\
1631\end{array}$ & $\begin{array}{l}42 \\
50 \\
51\end{array}$ & $\begin{array}{l}8 \\
7 \\
8\end{array}$ & $\begin{array}{l}26 \\
24 \\
18\end{array}$ & $\begin{array}{l}15 \\
12 \\
13\end{array}$ \\
\hline Boldon $^{9}$ & 1183 & 284 & 22 & 4 & 17 & 8 \\
\hline $\begin{array}{l}\text { Subsidy Rolls, } \\
\text { Sussex }\end{array}$ & $\begin{array}{l}1296 \\
1327 \\
1332\end{array}$ & $\begin{array}{l}7210 \\
7243 \\
6973\end{array}$ & $\begin{array}{l}3 \\
41 \\
40\end{array}$ & $\begin{array}{c}9 \\
14 \\
14.5\end{array}$ & $\begin{array}{c}9 \\
12 \\
11\end{array}$ & $\begin{array}{c}7 \\
12 \\
12.5\end{array}$ \\
\hline Surrey & 1332 & 5471 & 42 & 14 & 15 & 10 \\
\hline Kent & 1334 & 11016 & 33 & 20 & 10 & 9 \\
\hline Cambs & 1327 & 6385 & 23 & 25 & 14 & 12 \\
\hline Suffolk & 1327 & 11720 & 26 & 19 & 15 & 14 \\
\hline Somerset & 1327 & 11100 & 30 & 18 & 11 & 14 \\
\hline Worcester & $\begin{array}{l}1275 \\
1327\end{array}$ & $\begin{array}{l}6235 \\
4644\end{array}$ & $\begin{array}{l}14 \\
34\end{array}$ & $\begin{array}{l}14 \\
24\end{array}$ & $\begin{array}{l}14 \\
14\end{array}$ & $\begin{array}{l}12 \\
13\end{array}$ \\
\hline Warwickshire & 1332 & 5457 & 33 & 23 & 15 & 10 \\
\hline Salop & 1327 & 4897 & 31 & 11 & 17 & 9 \\
\hline Yorks & $\begin{array}{l}1297 \\
1301 \\
1327\end{array}$ & $\begin{array}{l}3402 \\
8699 \\
3848\end{array}$ & $\begin{array}{l}39 \\
37 \\
43\end{array}$ & $\begin{array}{l}8 \\
5 \\
5\end{array}$ & $\begin{array}{l}16 \\
18 \\
18\end{array}$ & $\begin{array}{c}16 \\
8 \\
8\end{array}$ \\
\hline Lancashire & 1332 & 2571 & 49 & 1 & 11 & 8 \\
\hline
\end{tabular}

\footnotetext{
${ }^{4}$ Liber Winton

${ }^{5}$ Pipe Roll

${ }^{6}$ Surveys: the first for the town, and the second for the large county manor.

${ }^{7}$ Shrewsbury Gild Merchant Rolls (Trans. SaAs, $2^{\text {nd }}$ ser., VIII (1896), 21-43; $3^{\text {rd }}$ ser. V (1905), 35-54, 81-100).

${ }^{8}$ Subsidy Rolls

${ }^{9}$ Boldon Buke
}

XLinguae, Volume 10, Issue 4, October 2017, ISSN 1337-8384, eISSN 2453-711X 
Variations in surnames took place because of variations in spelling, phonetic change, dialectal variations, and such. The modern form of many of our surnames is because of the spelling of some $16^{\text {th }}$ or $17^{\text {th }}$ century parson or clerk who had some education but who did not have any guidelines to the spelling of names. He used to write down the names phonetically, sometimes spelling the same name in different ways at different times; this variation in spelling often gives us the clue to the origin and meaning of the surnames. Alternative forms of a surname frequently provide proof of the development of different forms which are still found, e.g. Busby, Busbe, Bushby or Bussheby still survive as Busby or Bussby with a colloquial pronunciation Bushby. Some spelling changes do not affect the pronunciation; for example, both $F$ and $P h$ represent the same sound and are interchangeable: Fair, Phair; Fear, Phear etc. Similarly, $C$ often has the sound of $S$ or of $K$ : Cely, Seeley; Carslake, Karslake, and so on (Reaney, 1978: 27).

According to Reaney (1978), there is a common practice to prefix an inorganic $S$ to words starting with a consonant as in scrumple, snaisty (nasty). $S$ becomes $s h$ in the beginning such as in Shakesby for Saxby; in the middle such as in Pashley for Pasley; and in the end such as in Parish for Paris. There is an interchange between initial $P$ and B: Bullinger, Pullinger; Blamphin, Plamphin etc. The similar interchange of $T$ and $D$ is found in names like Tyson, Dyson; Dunstall, Tunstall etc. Loss of $r$ is found in names like Basham, Bassam from Barsham, and Funnell from Furnell. The final $n$ of names ending in -son sometimes becomes m: Haysom 'son of Hay' and Ransom 'son of Ran'. "In the treatment of the consonants $c, f$ and $s$ there was a huge difference between the North and the South. The Northern cald 'cold', calf preserved the sound of $k$ in Calf, Cawker and such but Southern ceald still survives with $c h$. The Southern voicing of $s$ is still preserved in some words. $F$ in the beginning in the South was pronounced $V$ which was also reflected in the spelling such as Venn for Fenn" (Reaney, 1978: 31).

\section{Local Surnames: Structure and Distortion}

As it is obvious, local surnames refer to the place from where a person has come, where he lives, or where he has his trade, service or occupation (Lofvenberg, 1942: xix). They were much more common than any other types of surnames and this was even the case in OE time. Many local surnames have survived up to the present days not only as surnames but also as place-names, which makes the matter more interesting. "A very large portion of local surnames are descriptive of the place where a man lived, near a forest, by a hill, in a valley, near a building, and the like. His place of residence could be described by any physical feature or by any object in the landscape which could easily be distinguished" (Reaney, 1978: 48). Originally, all these names began with a preposition ( $d e, a t, b y$, in, etc) and very often the definite article preceded the noun: Simon ate Hegge, Adam Ithelane, Richard a Paules stret, and so on. After the Norman Conquest, the usual preposition was de. In French names, which started with a vowel, this de often merged with names such as Danvers, Disney, Doyley and such, and sometimes with English names such as Dash, Delafield etc.

The method of indicating the place of origin was denoted by the use of descriptive adjectives, such as William le Northerne, 'William, the man from the North', Geoffrey le Westerne, 'Geoffrey, the man from the West' and so on. "Some of the toponymics have a French origin: Surridge, Surrage, (Geoffrey le Surreys); Estridge, (Peter Estreis). Other toponymics denote nationality: Wallis, (Ricard le Waleis); Gales, (Wulwurd le Galeys) (Reaney, 1978: 54). Sometimes the country of origin was specified and occasionally the town. The prepositional local surnames which were added to personal names were comparable to similar surnames attached to certain 
place-names and in both cases the purpose was the same-to distinguish identical names.

Corruptions of local surnames may take place because of factors such as contractions and peculiarity, imitative tendency, the distance a name travels from its origin, and different disguised endings. Generally, the further a local surname travelled from its home, the more it became distorted or changed. Name with the highest number of form of this class is probably Birkenshaw, 'birch wood', also spelt Berkenshaw, Burkenshaw, Burkinshear, Bircumshaw. "With the common change of $t$ for $k$, it becomes Birtenshaw, Bertenshaw, Burtonshaw, and even Buttonshaw. The replacement of -shaw by -shire is also seen in Blackshire and Kirbyshire, and the opposite change is found in Wilshaw. The change of -shaw to -shall in Upshall, Ringshall is a phonetic change which is opposite to the usual trends" (Weekley, 1974: 88). Some other examples of the corruption of county names are Barraclough which became Barrowcliff in Nottinghamshire, and reached London as Berrycloth and Berecloth. Sometimes, the distortions of local surnames took place because of imitative tendency, e.g. Strawbridge, Strowbridge for Stourbridge (in Worchester). Sometimes, a very slight change of spelling was rather confusing, for example, Wincer (Windsor), and occasionally alterations of the most violent kind took place, e.g. Vickerstaff, a Lancashire surname, apparently belonged to Bickerstaffe.

The most confusing and varied part of local surnames is the suffix portion where it was often found that-wood,-worth, -with, and -wade, were frequently interchanging, not only with each other, but also with the -ward of Anglo-Saxon personal names and with the adverbial -ward. Simply speaking, -wood in surnames is to be handled with caution because Stallwood is simply a corruption of the nickname Stalworth or Stalwart; on the contrary, Homeword is an alteration of Homewood, or for Holmwood, from ME holm meaning 'holly'. The Oak took the first place among names compounded from trees. "In most of the villages there were oak trees and the word often becomes -ack, -ick, -ock, -uck" (Weekley, 1974: 94).

Names such as Nash, Noakes, Nall are well known to be aphetic forms of atten ash, atten oaks, atten hall. With these go Niles, Nayland, Nyland (Thomas Attenylonde), Norchard, and Nendick. We also get aphetic forms in which the initial $A$ - alone disappears and the best examples of which are Twells, (at wells), Tash (at ash), Toe, Toes (Atto) etc (Weekley, 1974: 50). Besides the common Bycroft, Byford, Bysouth, Bywater, By- is also seen in Bygrave, Bygreaves, where the second element may mean 'grove' or 'quarry'. To these can be added Bidlake and Bidmead, Bitmeat, which contain the definite article. Names with Under- and Up- are fairly numerous and simple. "Undrell is for Underhill and Upfill for Upfield or Upfold. Sometimes in names like Upward, Downward, Downhard, Forward, Southward, -ward is substituted for -Wood, e.g. Homeward for 'holm wood' ('holly wood') (Weekley, 1974: 51-52)

\section{Some Case Studies}

Here, I will focus on four ME local surnames with their variants, and talk about the etymology of the names, their variations, and factors behind their variations.

\section{Aston and Easton}

Easton and Astons are very good examples of surnames sharing the same etymological root but having different regional and phonological variants. This name is of Anglo-Saxon origin and the general sources of the name are the Germanic elements -éast, meaning 'east', +tūn, 'an enclosure or settlement'. The OE phrase be easten tune means 'place to the east of a settlement or a village'. Although the variant Aston was common in West-Midlands, Easton seemed to be distributed in different parts of England, e.g. Huntingdonshire, Norfolk, Northamptonshire, Hampshire, Suffolk, Essex, Somerset, and Leicestershire. Old English $\bar{e} a$ could have been realised

XLinguae, Volume 10, Issue 4, October 2017, ISSN 1337-8384, eISSN 2453-711X 
as /ea/ in the West-Midland dialect instead of /e:a/ and then was monophthongised to /a/ in ME at a time when the orthography for the place-names resembled the phonetic spelling (Viereck et al., 2007: 96).

In addition, there might be three more etymologies for Easton: Firstly, "In Essex, it derived from OE èg, meaning 'island', + stān (as), meaning 'stone' and in Devon, from the personal names Alfrīc, AE elrīc or Eädstān” (Hanks \& Hodges, 1988: 161).

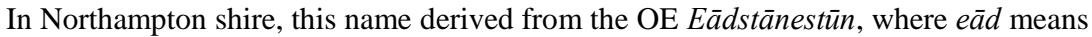
'prosperity', stān means 'a stone' and tūne means 'a settlement'. In this regard, Watts lists Great Easton and Little Easton in Essex, which were first mentioned in 1556 as Great Eyston and Little Eyston. He says, both the names stemmed from the $\mathrm{OE}$ personal name Aega+ stān (as), 'Æga's stone (s)' which was then assimilated to Easton or Aston (2004: 205). The first recorded spelling of this surname is that of John de Eston in 1299 in the 'Calendar of Court Rolls of Cambridge shire', Alan de Eston in 1273 in Oxfordshire, and Philipp ate Estone in 1327. Watts again states, "Aston might be the contraction form of ate stone 'dweller by the stone' or even a variant of OE æsc $\bar{a} s h+t \bar{u} n$ as in the surname Ashton" (2004: 24). From the survey on ME dialects for the West-Midland counties, it is found that there is a few examples of OE eāst 'east' with the first element East- in Leicestershire, Nottinghamshire, and Gloucestershire but Ast- is prevalent in other counties. The West-Midland area, therefore, had developed a distinct orthographic variant.

On the other hand, Aston is an English medieval surname and has three possible origins. Firstly, locational from the various place called Aston from the $7^{\text {th }}$ century words easst and $t \bar{u} n$ or the settlement in the east of a village, or in some cases the settlement by the ash tree. Secondly, the surname may stem from some Anglo-Saxon personal name, such as Aethelstan, comprised of aethel, meaning 'noble' and stan, meaning 'a stone'. Asthone de Sancto Luca is mentioned in documents relating to the Danelaw in Lincolnshire in 1140. Thirdly, the name might be topographical for a person who lived by a stone that was easily noticeable. Here, stān, 'stone', is preceded by preposition $a t$ and form the name Aston (at+stān). The first recorded spelling of the name is that of Richard de Aston in 1206 in the 'Curia Regis Rolls' of Gloucestershire.

Apart from having the origin of Easton in Essex, Devon, Norfolk and Suffolk, a majority of occurrences between the $16^{\text {th }}$ and $19^{\text {th }}$ centuries are situated in areas such as West Lothian, Lanarkshire, Roxburghshire, Midlothian, Lincolnshire, Sussex and Northumberland. Interestingly, there are rarely any events for Easton in the West Midland area for the period of four centuries. Aston is circulated and concentrated in the West Midlands counties like Staffordshire, Worcestershire, Warwickshire, and Herefordshire from the $16^{\text {th }}$ century onwards. According to the UK census data of 1881, the two names share almost the same number of occurrences: Aston 4978 and Easton 4551. Easton still prevalent in Scotland, clustered in the North and the SouthEast of England and Devon, but is almost absent in West Midlands counties. On the other hand, five West Midlands counties: Staffordshire (1366 occurrences), Warwickshire (779), Worcestershire (547), Shropshire (232), and Herefordshire (232) share $59.6 \%$ of the total occurrences for Aston. Again in 2004, these counties contributed to the $40.5 \%$ of the 7956 entries in the whole UK. 


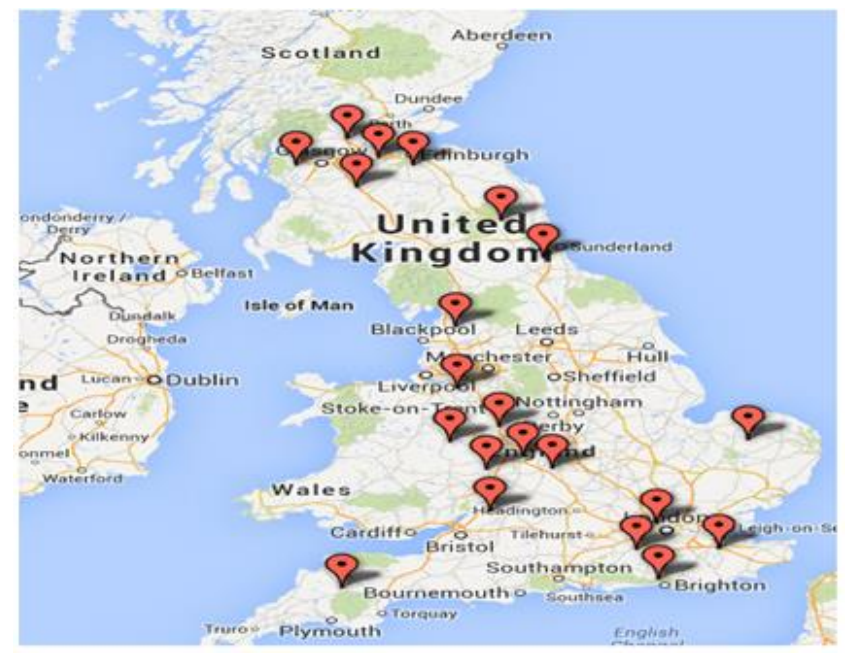

Map 1: Distribution of Aston and Easton

\begin{tabular}{|c|c|c|c|c|c|c|}
\hline \multirow[t]{2}{*}{ Place (UK) } & \multicolumn{3}{|c|}{ Aston } & \multicolumn{3}{|c|}{ Easton } \\
\hline & 1881 & 1911 & 2004 & 1881 & 1911 & 2004 \\
\hline Staffordshire & 1366 & 1796 & 705 & 14 & 18 & 58 \\
\hline Warwickshire & 779 & 1029 & 321 & 9 & 32 & 71 \\
\hline Worcestershire & 547 & 630 & NI & 7 & 8 & $\mathrm{NI}$ \\
\hline Middlesex & 363 & 132 & NI & 383 & 202 & NI \\
\hline Lancashire & 313 & 552 & 217 & 136 & 182 & 98 \\
\hline Gloucestershire & 306 & 338 & 259 & 21 & 12 & 104 \\
\hline Shropshire & 232 & 258 & 262 & 4 & 4 & 33 \\
\hline Yorkshire & 188 & 443 & $\mathrm{NI}$ & 410 & 540 & $\mathrm{NI}$ \\
\hline Cheshire & 161 & 261 & 214 & 20 & 20 & 68 \\
\hline Surrey & 119 & 83 & 118 & 343 & 231 & 74 \\
\hline Lanarkshire & 20 & $\mathrm{NI}$ & 9 & 425 & $\mathrm{NI}$ & 418 \\
\hline Midlothian & 3 & NI & 16 & 213 & NI & 278 \\
\hline Devon & 23 & 3 & 140 & 206 & 29 & 329 \\
\hline Northumberland & 9 & 23 & 37 & 169 & 299 & 169 \\
\hline Kent & 34 & 63 & 110 & 164 & 230 & 330 \\
\hline Sussex & 16 & 16 & $\mathrm{NI}$ & 158 & 223 & NI \\
\hline Norfolk & 16 & 8 & 57 & 143 & 149 & 160 \\
\hline Stirlingshire & 0 & NI & 4 & 137 & NI & 338 \\
\hline West Lothian & 0 & $\mathrm{NI}$ & 6 & 127 & NI & 258 \\
\hline Durham & 39 & 66 & 75 & 118 & 296 & 76 \\
\hline Renfrewshire & 5 & 0 & 0 & 103 & 0 & 65 \\
\hline
\end{tabular}

Table 2: Distribution of Aston and Easton

NI: No Information is collected.

The presence of Aston is stronger mainly in the West Midland counties with a small presence of Easton. On the other hand, Easton is dominant in the Southern part of 
Scotland and Northern border region. Both Aston and Easton show their high presence in Wales and the South-East of England, with Easton is the more frequent variant.

\section{Oakes, Noakes and Roake}

Surname variants can also develop from grammatical misinterpretation or lost knowledge of the function of prepositional elements. "Surnames with an initial vowel were likely to be subject to a wrong separation of article and noun, e.g. $\langle\mathrm{n}\rangle$ of ME atten because the ending -ten was no longer recognised as the dative singular of the article and was added to the noun as in Oak>Noak" (Forster, 1978: 194). This name with variant spelling Oak, Oake, Oaks, Oke, Noak, Noake, Noakes, Nock, Noaks, Noke and Nokes derives from the OE pre- $7^{\text {th }}$ century $a c$, ME Oke meaning an Oak tree and was initially given to a person whose dwelling was located by a well-known Oak tree. Aten Oke and Atten Oak (at the oak) were the original forms and when the preposition began to drop from this kind of surname, the final $-n$ was attached to the designation of the tree and we obtained the form Noake with the vulgar plural form Noakes. Apart from Noake, we have Rock (Worcester), and Rook (Devon) from atter oak or ater oak, meaning 'by the oak'. The first recorded spellings of the name are Thomas del Oke (1275), Adam at the Ock (1273), Thomas atten Oke (1296), John ate Noke (1327), and Robert ate Nokes (1332).

The surname Roake has several possible origins. Firstly, it can be residential for somebody living near a notable crag and this forms the $7^{\text {th }}$ century word 'rocc'. Secondly, it can be residential also but for somebody living near a large oak tree. This derives from the ME phrase atter oke, meaning 'at the oak tree'. Thirdly, it can originate either from the village of Rocks in Northumberland, which is on a rock, or from Rock in Worcestershire, which is the combined form of atter oke. The first recorded spelling of the family name is that of Robert del Roc dated in 1182 for the county of Worcestershire. Although generally, the name was given to someone who lived near an oak tree or in an oak wood, in some cases, it can be given to someone who is strong like an oak.

By the $18^{\text {th }}$ century, Oakes has concentrated in the area of Cheshire and Staffordshire and by the $19^{\text {th }}$ century, areas like Lancashire, Cheshire, Staffordshire, West Riding Yorkshire, Derbyshire, Worcestershire, Warwickshire, and Shropshire contributed to the $77 \%$ of the total events for Oakes. "The few early records of Noakes in the $17^{\text {th }}$ and $18^{\text {th }}$ century are concentrated in the South-Eastern tip of England with Kent and Sussex becoming the only notable cluster by the $19^{\text {th }}$ century and between 1500 and 1900 about $81 \%$ of the total events for Noakes were recorded in these two counties" (Viereck et al., 2007: 150). There is a clear pattern of distribution with both the variants; Oakes occur exclusively in the North and Noakes in the South-East. Although it seems that Oakes concentrate in the place of origin, it is also mentionable that Noakes concentrate in Kent and in Sussex. 


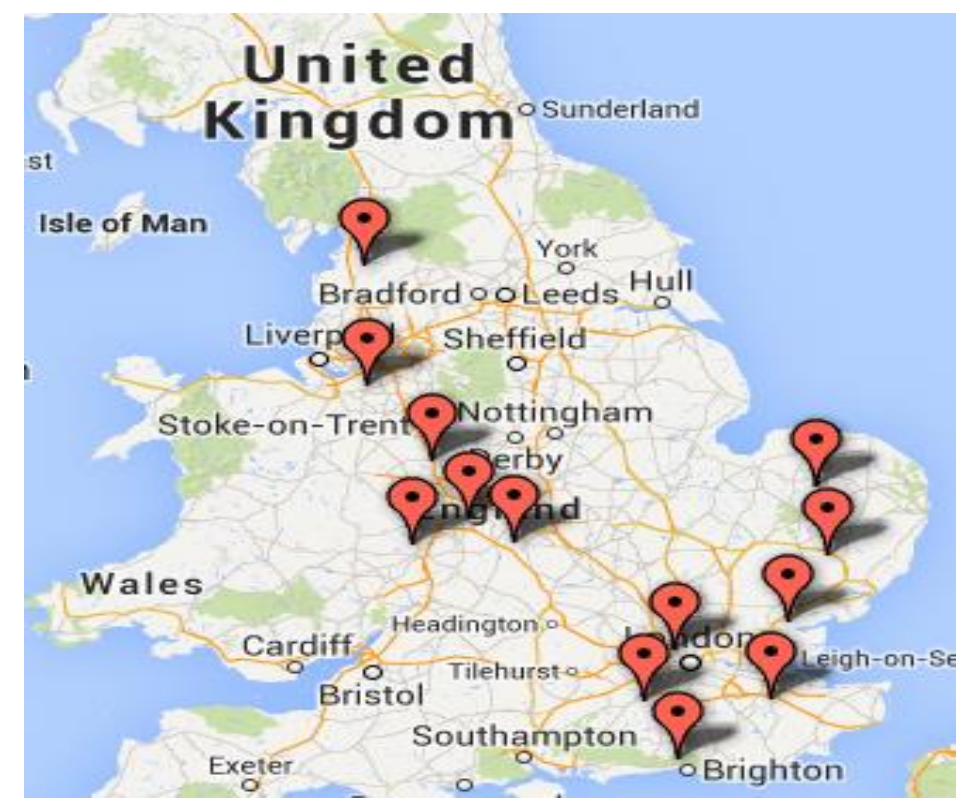

Map 2: Distribution of Oakes, Noakes, and Roake

\begin{tabular}{|c|c|c|c|c|c|c|c|c|c|}
\hline \multirow{2}{*}{ Place (UK) } & \multicolumn{3}{|c|}{ Oakes } & \multicolumn{3}{c|}{ Noakes } & \multicolumn{3}{c|}{ Roake } \\
\cline { 2 - 11 } & 1881 & 1911 & 2004 & 1881 & 1911 & 2004 & 1881 & 1911 & 2004 \\
\hline Lancashire & 961 & 1577 & 367 & 40 & 52 & 32 & 8 & 4 & 2 \\
\hline Cheshire & 662 & 879 & 865 & 7 & 15 & 27 & 0 & 1 & 0 \\
\hline Staffordshire & 488 & 651 & 373 & 125 & 190 & 75 & 1 & 0 & 0 \\
\hline Yorkshire & 446 & 572 & NI & 29 & 51 & NI & 1 & 1 & NI \\
\hline Middlesex & 238 & 124 & NI & 424 & 141 & NI & 41 & 40 & NI \\
\hline Worcestershire & 226 & 291 & 233 & 28 & 20 & 14 & 0 & 0 & 1 \\
\hline Warwickshire & 161 & 159 & 123 & 43 & 56 & 36 & 7 & 2 & 1 \\
\hline Norfolk & 149 & 187 & 174 & 2 & 4 & 39 & 0 & 3 & 0 \\
\hline Suffolk & 144 & 154 & 111 & 3 & 3 & 59 & 0 & 0 & 6 \\
\hline Surrey & 140 & 131 & 135 & 165 & 167 & 175 & 139 & 81 & 78 \\
\hline Sussex & 45 & 60 & 55 & 578 & 531 & 511 & 1 & 4 & 7 \\
\hline Kent & 58 & 103 & 192 & 286 & 407 & 303 & 4 & 26 & 38 \\
\hline Essex & 18 & 97 & 236 & 154 & 370 & 327 & 9 & 6 & 31 \\
\hline
\end{tabular}

Table 3: Distribution of Oakes, Noakes, and Roake NI: No information is collected.

Regarding the distribution of Roake, there is the confusion of genders about the articles atten, atter, and atte which seemed to be an exclusive feature of South-Eastern region. The surname Roake concentrated in the South, especially in Surrey, Middlesex, and Berkshire between 1500 and 1900. Viereck et al. pointed out, "The 
surname variants originating from the grammatically correct gender atter have been recorded less frequently than the variants emerged out of the application of wrong gender, e.g. atten" (2007: 150). Roake is more concentrated in the region comprising Surrey, Greater London, Kent, and Essex and it can be said that mainly in the southeast of England Oakes became Noakes or Roake.

\section{Fenn and Venn}

"The unusual surnames Fenn and Venn are of medieval English origin and one of the first recorded which developed from OE fenn meaning 'a marsh' and described someone who lived in a low lying marshy area” (Hanks \& Hodges, 1988: 179). Both Fenn and Venn are both topographic surnames for someone who lived in a low-lying marshy area, or regional and locational for a former resident of the Fen county of East Anglia in particular. They originated in the Fens "a flat low-lying tract of land with rivers, streams, and manmade channels that drain into The Wash which comprises a large region of east and south Lincolnshire, north and east Cambridgeshire, and northwest Norfolk" (Room, 1988: 136).

Early examples of the surname Fenn are mainly restricted to the district around the Broads in East Norfolk with a smaller number in the West. "The early samples of the surname are that of Godwin de la Fenna in 1176 in Devon, Ralph de Fenne in 1190 in Lincolnshire, Isabella ate Fenne in 1273 in Oxforshire, Robert de la Fenne in Somerset, and John ate Venne in 1327" (Reaney, 1997: 166). The interesting thing is the Southern variants of Fenn where /f/ became /v/. The unvoiced fricative developed variedly from regions to regions and was voiced in the South of England, especially when preceding a vowel. Venn is a Devonshire place-name and was mainly distributed in Devon and Somerset.

Whereas Fenn is distributed in Suffolk, Norfolk, Essex, Hertfordshire and Kent, Venn is rarely present there and totally absent in Lincolnshire. Venn is really strong in Gloucestershire and its distribution pattern runs from the north of the West Midlands to the South and to the Eastern shore. The analysis of census data reveals that Fenn has concentrated in the counties of the Mid East, Surrey and Kent, and according to 1881 census, Venn comprises approximately half as many entries as Fenn. According to the 1881 census, Middlesex, Suffolk, Norfolk, Essex, Surrey, Staffordshire, and Kent have shared $64.2 \%$ of all events for Fenn. On the other hand, the distribution of Venn is limited to Somerset, Devon, and Gloucestershire with $45.6 \%$ of all events, and Middlesex, Surrey, Sussex, and Kent occupy $30.7 \%$ of the total events for Venn. 


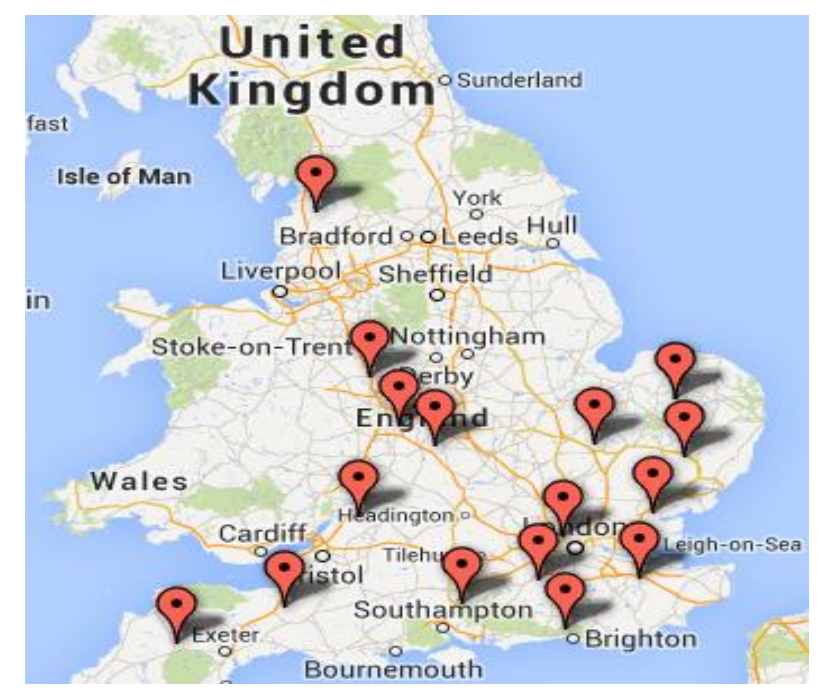

Map 3: Distribution of Venn and Fenn

\begin{tabular}{|c|c|c|c|c|c|c|}
\hline \multirow{2}{*}{ Place (UK) } & \multicolumn{3}{|c|}{ Venn } & \multicolumn{3}{c|}{ Fenn } \\
\cline { 2 - 7 } & 1881 & 1911 & 2004 & 1881 & 1911 & 2004 \\
\hline Somerset & 289 & 31 & 133 & 0 & 2 & 30 \\
\hline Devon & 216 & 21 & 113 & 18 & 4 & 102 \\
\hline Middlesex & 157 & 84 & NI & 596 & 249 & NI \\
\hline Surrey & 128 & 83 & 106 & 246 & 196 & 149 \\
\hline Gloucestershire & 118 & 214 & 235 & 72 & 61 & 49 \\
\hline Sussex & 82 & 111 & 101 & 53 & 77 & 83 \\
\hline Kent & 52 & 55 & 94 & 213 & 160 & 202 \\
\hline Lancashire & 45 & 37 & 24 & 87 & 205 & 115 \\
\hline Hampshire & 34 & 41 & 167 & 37 & 46 & 75 \\
\hline Suffolk & 11 & 28 & 16 & 356 & 372 & 277 \\
\hline Norfolk & 8 & 7 & 14 & 272 & 306 & 357 \\
\hline Essex & 7 & 32 & 42 & 272 & 506 & 443 \\
\hline Staffordshire & 8 & 8 & 16 & 143 & 159 & 64 \\
\hline Cambridgeshire & 4 & 2 & 20 & 103 & 163 & 146 \\
\hline Yorkshire & 3 & 18 & NI & 93 & 219 & NI \\
\hline Warwickshire & 24 & 41 & 31 & 57 & 87 & 43 \\
\hline
\end{tabular}

Table 4: Distribution of Venn and Fenn.

NI: No Information is collected.

Venn is still distributed exclusively in the Southern counties. The South is divided among the two variants into West and East with both variants taking supremacy in one of the directions. Fenn dominates the South East where both variants are mostly concentrated in the entire Midlands apart from Gloucestershire, Hereford, and Worcester. Gloucestershire and Hampshire are the eastern boundaries of the area where voiced initial $/ v /$ dominates over the unvoiced variant. 


\section{Stanford and Staniforth}

"The place-name element -ford is one of the most common ones being cognate with Old Frisian forda, Old Norse ford, Old High German furt and Old Saxon vord; its variant element -forth is heavily concentrated in the Northern counties like Lancashire, North, East and West Riding Yorkshire" (Viereck et al., 2007: 104). This long established surname is of Anglo-Saxon origin, and is a locational one from any of the South England places, such as Bedfordshire, Berkshire, Hertfordshire, Kent, and Essex. "It derives from OE stān 'stone' + ford 'ford'; hence 'stony ford' or ' a ford made of stone"” (Hanks \& Hodges, 1988: 508). The above places were recorded as stanford and stanforda in the Domesday Book. Early examples of the surname include William de Stanford (1191), Adam de Stanford in Oxfordshire (1273), and Symon de Stanford in Hutingdonshire (1275).

There are lots of variants of Stanford: Standford through the addition of a consonant after $/ \mathrm{n} /$; Stamford due to the regressive assimilation; Staniford as the result of a transitional vowel between two consonants; Stanforth and Staniforth due to the suffix -forth since -ford often rendered -forth in northern dialects. Stanford and Staniforth are the two strongest variants. According to 1881 census, Stanford has strong hold in Middlesex (323 occurrence), Surrey (317), Sussex (310), Kent (301) and Staffordshire (218). Among other variants with suffix -ford, e.g. Staniford, Standford and Stamford, Stamford is the strongest with 106 entries in Sheffield, 92 in Middlesex, 60 in Surrey, and 57 in Cambridgeshire. Staniford has its highest number of occurrence in Berkshire (32), and Stanford has in Kent with only 29 occurrences. Among the variants with suffix -forth, Staniforth is much stronger than Stanforth with a maximum occurrence of 691 in Yorkshire; Stanforth also has its highest occurrence in Yorkshire although with only 63 occurrences.

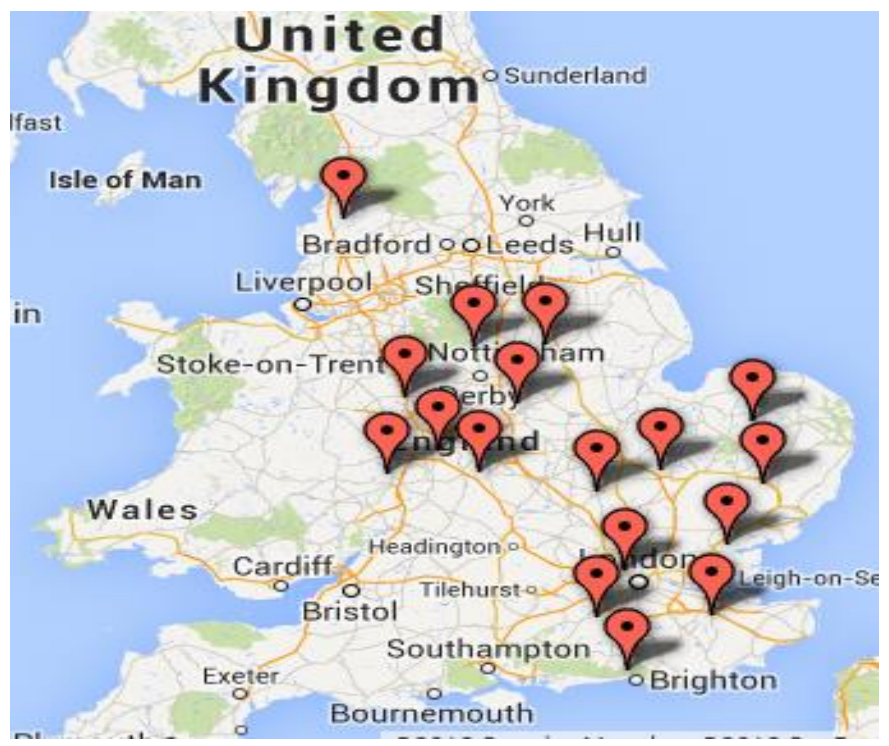

Map 4: Distribution of Stanford and Staniforth

\begin{tabular}{|l|c|c|c|c|c|c|}
\hline Place (UK) & \multicolumn{3}{|c|}{ Stanford } & \multicolumn{3}{c|}{ Staniforth } \\
\cline { 2 - 7 } & 1881 & 1911 & 2004 & 1881 & 1911 & 2004 \\
\hline
\end{tabular}




\begin{tabular}{|c|c|c|c|c|c|c|}
\hline Middlesex & 323 & 124 & NI & 24 & 17 & NI \\
\hline Surrey & 317 & 232 & 233 & 10 & 1 & 42 \\
\hline Sussex & 310 & 371 & 330 & 1 & 3 & 21 \\
\hline Kent & 301 & 233 & 304 & 3 & 11 & 22 \\
\hline Staffordshire & 218 & 287 & 96 & 0 & 10 & 7 \\
\hline Cambridgeshire & 97 & 141 & 98 & 0 & 1 & 9 \\
\hline Norfolk & 82 & 89 & 72 & 0 & 3 & 12 \\
\hline Lancashire & 79 & 137 & 86 & 77 & 149 & 43 \\
\hline Essex & 79 & 208 & 240 & 0 & 1 & 24 \\
\hline Warwickshire & 67 & 183 & 82 & 14 & 20 & 19 \\
\hline Worcestershire & 67 & 127 & 119 & 1 & 9 & 17 \\
\hline Bedfordshire & 53 & 104 & 52 & 1 & 3 & 19 \\
\hline Suffolk & 44 & 58 & 73 & 0 & 4 & 16 \\
\hline Yorkshire & 43 & 99 & NI & 691 & 803 & NI \\
\hline Derbyshire & 4 & 45 & 34 & 125 & 124 & 157 \\
\hline Leicestershire & 27 & 46 & 55 & 65 & 93 & 76 \\
\hline Nottinghamshire & 7 & 22 & 33 & 54 & 103 & 107 \\
\hline
\end{tabular}

Table 5: Distribution of Stanford and Staniforth

NI: No Information is collected.

The first occurrences for Stanford in the $16^{\text {th }}$ century are recorded in Sussex, Worcestershire, Hampshire and Lincolnshire. There is hardly any event in the Northern part in the $16^{\text {th }}$ and $17^{\text {th }}$ century. In the $18^{\text {th }}$ and $19^{\text {th }}$ century, there is a significant cluster in the Southeast of Sussex with a rare presence in the Northern part. In the case of Staniforth, Derbyshire, Nottinghamshire, and West Riding Yorkshire hold almost $65.2 \%$ of all the events between 1500 and 1900; however, only a few events are found in the Southeast of England during the same time span. Stanford is still stronger variant than Staniforth. The element -forth is really strong in Yorkshire as it has always been, and is almost absent in the South of England comparing to variants with - ford.

\section{Conclusion}

We have seen how ME surnames vary from place to place because of the way they are spelt, because of the phonetic change and, most importantly, because of the dialectal variation. Variations in local surnames also take place because of the distance a name travels from its origin, of addition of different suffixes, and of different peculiarities. Aston and Easton have the same etymology but differ from each other on regional and phonological perspectives. In the case of Oakes, Noakes, and Roake, variations arise from grammatical misinterpretations or the knowledge of the function of prepositional elements. When preposition started to drop from names like Atten Oke and Atter Oak, the final $-n$ and $-r$ was attached with the name of the tree and we find the variant Noake and Roake. Initial $F$ - in the South was pronounced $V$, which we find in Venn and Fenn. Staniforth is a variant of Stanford and here the variation arises because of the dialectal variations of suffix -ford and -forth. In Northern dialect -ford is often rendered -forth. At present Aston is stronger in the West Midlands counties whereas Easton is more dominant in the Northern border region and the Southern part of Scotland. Fenn dominates over Venn in the Southeast areas apart from Gloucestershire and Worcester; on the other hand, Venn is stronger than Fenn in Gloucestershire and Hampshire. Stanford is stronger than Staniforth in the South of England but the element -forth has its strongest base in Yorkshire. Oakes concentrates in its place of origin, and in the Southeast of England it becomes Noakes and Roake. 


\section{Bibliographic references}

COLTTLE, B. 1978. The penguin dictionary of surnames ( $2^{\text {nd }}$ ed.). London: Allen Lane.

EKWALL, E. 1922. Place-names of Lancashire. Manchester: Manchester University Press.

Forebears - Genealogy resources online. (n.d.). Retrieved from http://www.forebears.co.uk

FRANSSON, G. 1935. Middle English surname of occupation 1100-1350. Lund: Hakan Ohlsson.

Google Fusion Tables. (n.d.). Retrieved from http://www.tables.googlelabs.com

HANKS, P. - HODGES, F. 1988. A dictionary of surnames. Oxford: Oxford University Press.

HOUGH, C. 2012. "Linguistic levels: Onomastics". In A. Bergs \& L. Brinton. (Eds.), English historical linguistics: An international handbook (pp. 212-223). Berlin: De Gruyter Mouton.

LÖFVENBERG, M. T. 1942. Studies on Middle English local surnames. Lund: Hakan Ohlsson.

MCKINLEY, R. 1990. A history of British surnames. London \& New York: Longman.

REANEY, P. H. 1976. The origin of English place-names $\left(5^{\text {th }}\right.$ ed.). London: Routledge and Kegan Paul.

REANEY, P. H. 1978. The origin of English surnames ( $4^{\text {th }}$ ed.). London: Routledge \& Kegan Paul.

REANEY, P. H. - WILSON, R.M. 1976. A dictionary of British surnames ( $2^{\text {nd }}$ ed.). London: Routledge \& Kegan Paul.

REANEY, P. H. - WILSON, R.M. 1997. A dictionary of English surnames (3 ${ }^{\text {rd }}$ ed.). Oxford: Oxford University Press.

RICHARD, C. 2006. "Names". In R. Hogg \& D. Denison (Eds.), A history of the English language (pp. 312-351). Cambridge: Cambridge University Press.

ROOM, A. 1988. Dictionary of place-names in the British isles. London: Bloomsbury.

The internet surname database: Last name origins. (n.d.). Available online: http://www.surnamedb.com

Trace your ancestors with the 1911 census. (n.d.). Available online: http://www.uk1911census.com

VIERECK, W. et al. 2007. An atlas of English surnames. Frankfurt am Main: Peter Lang.

WATTS, V. E. (Ed.). 2004. The Cambridge dictionary of English place-names: Based on the collections of the English place-name society. Cambridge: Cambridge University Press.

WEEKLEY, E. 1922. The romance of names ( $3^{\text {rd }}$ ed.). Cambridge: Cambridge University Press.

WEEKLEY, E. 1974. Surnames ( $4^{\text {th }}$ ed.). Folcroft Library Editions.

Words: 6111

Characters: 35465 (19,7 standard page)

Md Abu Shahid Abdullah

Lecturer, Department of English

University of Asia Pacific

74/A Green Road, Dhaka, Bangladesh

Jwl_abdullah@yahoo.com 